SOI: $\underline{1.1 / \mathrm{TAS}}$ DOI: $\underline{10.15863 / \mathrm{TAS}}$ International Scientific Journal Theoretical \& Applied Science

p-ISSN: 2308-4944 (print) e-ISSN: 2409-0085 (online)

Year: $2018 \quad$ Issue: 12 Volume: 68

Published: $30.12 .2018 \quad$ http://T-Science.org
QR - Issue
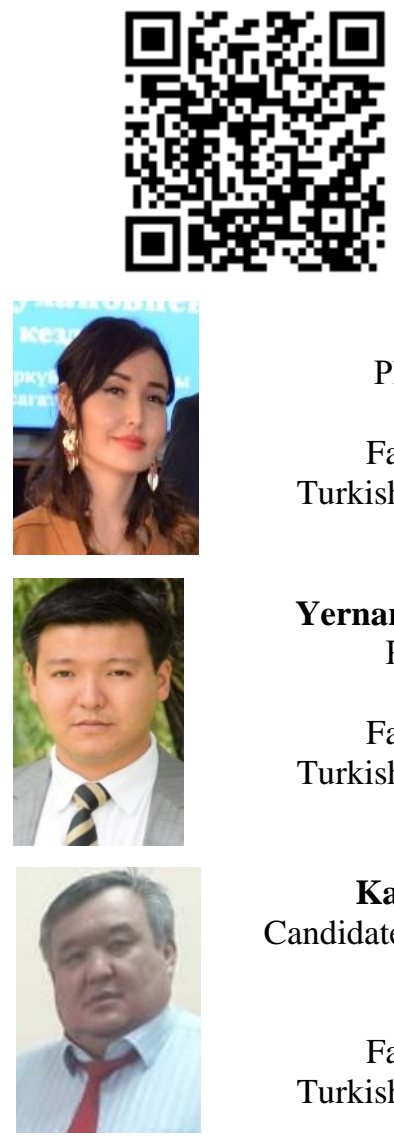

QR - Article

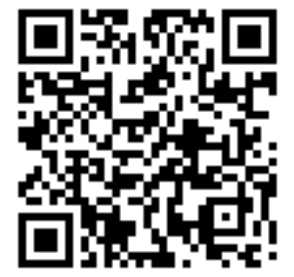

Azhar Nartai

$\mathrm{PhD}$ student of «Jurisprudence» Department of Social Science

Faculty in International KazakhTurkish University after H.A.Yessevi sarapshy.tk@mail.ru

Yernar Sailaubekovich Shalkharov $\mathrm{PhD}$ doctor of «Jurisprudence» Department of Social Science

Faculty in International KazakhTurkish University after H.A.Yessevi yernar_shalkharov@bk.ru

Kairat Turlybaevich Bitemirov Candidate of law science., ass.professor Chief of «Jurisprudence» Department of Social Science Faculty in International KazakhTurkish University after H.A.Yessevi bitemirov_kayrat@mail.ru

\title{
THE PLACE OF ACTS REGARDING TO GENETIC ENGINEERING IN THE SYSTEM OF LEGAL REGULATION (LEGAL ANALYSIS)
}

Abstract: Being a legal state, the Republic of Kazakhstan is obliged first of all to consider all functioning segments from the position of legal analysis. Genetic engineering is also no exception. Designating the position of Kazakhstani legislation on the concept of human genetic material, it is equally important to designate the degree of maneuverability, the coefficient of elasticity of consideration of the human genome in the system of normative legal acts. Consideration of such in civil law is impossible due to the lack of elaboration of the provisions. Nevertheless, in criminal law there are two distinctions between "person and citizen" and "owner and donor", which should be considered together in relation to the human genetic material in the context of considering human tissues. The present was taken as a basis because of the lack of regulation of the concept of genetic material in the system of current legislation, giving preference to organs and tissues.

Key words: human genetic material, biological samples, serums, human tissues, human cells, intercellular substance, biomedical law, biomedical criminology, genetic forensics.

Language: English

Citation: Nartai, A., Shalkharov, Y. S., \& Bitemirov, K. T. (2018). The place of acts regarding to genetic engineering in the system of legal regulation (legal analysis). ISJ Theoretical \& Applied Science, 12 (68), $373-375$.

Soi: http://s-o-i.org/1.1/TAS-12-68-56 Doi: croskef https://dx.doi.org/10.15863/TAS.2018.12.68.56

\section{Introduction}

In accordance with the Constitution of the Republic of Kazakhstan, motives of origin are not grounds for discrimination against anyone (1). Consequently, at the legislative level it is wrong to separate the notion of a person and a citizen from the position of oppression of genetic rights to biological material. So in the criminal law there is a normative element regarding the coercion to seize or unlawfully seize the organs and tissues of a person, in which such is punished and implies criminal liability, while not separating the victim from the concepts of citizen and person (2). This shows that criminal law does not divide a person into citizens. This criminal law also 


\begin{tabular}{|c|c|c|c|c|c|c|}
\hline \multirow{4}{*}{ Impact Factor: } & ISRA (India) & $=3.117$ & SIS (USA) & $=0.912$ & ICV (Poland) & $=6.630$ \\
\hline & ISI (Dubai, UAI & $=0.829$ & РИНЦ (Russia) & $=0.156$ & PIF (India) & $=1.940$ \\
\hline & GIF (Australia) & $=0.564$ & ESJI (KZ) & $=5.015$ & IBI (India) & $=4.260$ \\
\hline & JIF & $=1.500$ & SJIF (Morocco) & $=5.667$ & & \\
\hline
\end{tabular}

presupposes a regulatory element singled out as "trafficking in persons", which also suggests criminal liability measures in cases of trafficking in persons for entities trading in such persons, also without assuming a separation between a person and a citizen (3). Another regulatory element of criminal law also regulates a certain degree of criminal responsibility in cases of violation of the equality of rights of a person and a citizen, directly or indirectly, where the concept of "by motive of origin" is in the first place (4). This also treats the unimportance of the appearance of a person into the world naturally or artificially, giving preference to his human essence, in which he in principle does not even have to be a citizen, as evidenced by the normative emphasis, in which exactly the term "citizen" is indicated in brackets, not the other way around. At the same time, the main emphasis is also placed on human organs and tissues. In the legislation of the Republic of Kazakhstan "on public health and the health care system," human tissue has been designated as a collection of cells and an intercellular substance that have the same structure, function, and origin (5).

\section{Materials and Methods}

Kazakhstan studies in this direction have deepened when designating the legal status of tissues in the system of regulatory and legal elements, in which it was indicated that human tissues, being an integral component, imply thorough and detailed identification of each cell and substance in its components (6). At the same time, by detailing the present up to the level of the cell, it was determined that the cell also has a certain legal status of a legal entity when it is illegally used or illegally withdrawn without the consent of the holder (7). Focusing on the notion of "owner of cells and intercellular substance", an analogy with the concept of "donor of cells and intercellular substance" was proposed, in which the owner and donor were asked by the same person (8). Logically going through the regulations in this logically, the level of manipulation was suggested, where, with the voluntary withdrawal, the "owner of the cells and the intercellular substance" can be classified as a donor, and in the case of elimination or illegal withdrawal remains the owner (9). Thus, it was found that if the disputes about the identification of the owner and the donor take place in the system of regulatory acts as subjects, then the objects must be identified in detail, which are human tissues with all its components (10).

Russian legislation means its advanced technologies in the field of genetic engineering by means of a completely new area of jurisprudence, medicine, biology, genetics and biotechnology and, in general, biomedical law (11). In accordance with this direction, the lion's share of the legal designations that make up the human genome, due to the impossibility of studying this in the normative channel, was identified in the direction of Russian biocryminology, where alternative forensic scenarios were played out allowing the investigative experiment (12). After a thorough analysis, this direction of biomedical law was compared with the direction of forensic science abroad, which, by analogy, found a number of precedents that helped identify the components of human tissues in the system of legal acts (13). Thus, the present allowed the identification and possibility in the Russian Federation of citizens, if necessary and with the appropriate expression of will, to consider cells as part of themselves and operate with them using specialized contract manufacturing (14). Consequently, being a donor, the present involves the provision of cells voluntarily, as an object of trafficking, as well as theft with involuntary seizure (15).

American studies have reacted differently to the question of considering acts in the field of genetic engineering in the legal regulation system, denoting cases in the case-law system of continental American law, in which objects of genetic engineering are not an exception (16). So by virtue of the emergence of necessity and with a sufficient basis of previously conducted precedents, human cells can even be considered in a certain form of ownership, which can be subject to commercialization and be considered respectively in the system of current legislation (17). Therefore, by giving rise to a precedent of law in the field of genetic engineering, the legal criteria for manipulation can be sufficiently elastic in the field of professional operating (18). This factor is quite positive for the development of genetic engineering in this legal space of the state territorial unit as it eliminates the bureaucratic factor as an obstacle (19). Nevertheless, the ethical side of genetic engineering is a sufficient reason to substantiate the legal position in the field of manipulation in genetic engineering (20).

\section{Conclusion}

Thus, as a conclusion, it can be stated that the system of regulatory acts of the Republic of Kazakhstan does not provide for a provision regarding the consideration of genetic material in general, which implies the need to consider it in the system of legal regulation of operations related to maneuvers over the genome detailing it to the cell and intercellular substances. 


\begin{tabular}{lllllll} 
& ISRA (India) & $=\mathbf{3 . 1 1 7}$ & SIS (USA) & $=\mathbf{0 . 9 1 2}$ & ICV (Poland) & $\mathbf{= 6 . 6 3 0}$ \\
Impact Factor: & ISI (Dubai, UAE) $=\mathbf{0 . 8 2 9}$ & PUHL (Russia) $=\mathbf{0 . 1 5 6}$ & PIF (India) & $\mathbf{= 1 . 9 4 0}$ \\
& GIF (Australia) & $=\mathbf{0 . 5 6 4}$ & ESJI (KZ) & $=\mathbf{5 . 0 1 5}$ & IBI (India) & $\mathbf{4 . 2 6 0}$ \\
& JIF & $\mathbf{1 . 5 0 0}$ & SJIF (Morocco) & $=\mathbf{5 . 6 6 7}$ & & \\
\hline
\end{tabular}

\section{References:}

1. (n.d.). The Constitution of the Republic of Kazakhstan., Article 14, part 1.

2. (n.d.). Criminal Code of the Republic of Kazakhstan., Article 116, part 1.

3. (n.d.). Criminal Code of the Republic of Kazakhstan., Article 128, part 1.

4. (n.d.). Criminal Code of the Republic of Kazakhstan., Article 145, part 1.

5. (n.d.). KRK “on People's Health and the Healthcare System”, Article 1, Part 1, Subpart 107-1.

6. Shalkharov, Y. S. (n.d.). The concept and legal status of human tissues in the system of regulatory acts of the Republic of Kazakhstan.

7. Shalkharov, Y. S. (n.d.). The concept and legal status of cells and human intercellular substance in the system of regulatory legal acts of the Republic of Kazakhstan.

8. Shalkharov, Y. S. (n.d.). Donor and owner of cells and intercellular substance in the system of regulatory legal acts of the Republic of Kazakhstan.

9. Shalkharov, Y. S. (n.d.). Legal aspects of equating the owner of the cells and the intercellular substance to such donors.

10. Shalkharov, Y. S. (n.d.). The level of legal designation of human tissue, including all its components in the system of regulatory and legal acts of the Republic of Kazakhstan.

11. Romanovsky, G. B., et al. (2015). Biomedical law in Russia and abroad. monograph. Science. ed. (p.368). M.: Prospectus.

12. Romanovsky, G. (n.d.). Entertaining biocryminology. Textbook., ISBN: 978-5-39227434-5, (p.200).

13. Mokhov, A., \& Tarusina, M. (2015). Biomedical law in Russia and abroad. Textbook, ISBN: 9785392178650., (p. 368).

14. Zakharov, I. A. (2002). To give birth cannot be cloned. Science and life, N 9, 34-39.

15. Gogolevsky, A., \& Zdanovsky, V. (1998). Cloning. Reproduction problems, $N 3,11$.

16. Collins, F. S., \& Jegalian, K. G. (1999, Dec.). Deciphering the Code of Life. Scientific American, 50.

17. Venter, I. C., et al. (2001). The sequence of the human genome. Science, № 291, 1304-1351.

18. Baltimore, D. (2001). Our genome unveiled. Nature, № 409, 814-816.

19. Wolfsberg, T. G., Mcintyre, I., \& Schuler, G. D. (2001). Guide to the draft human genome. Nature, № 409, 824-826.

20. Snel, V., Bork, P., \& Huynen, M. (2000). Genome evolution: gene fusion versus gene fission. Trends in Genetics, V. 16, 9-11. 